\title{
Repeated Planning Applications by Developers under Statutory Zoning: a Hong Kong Case Study of Delays and Design Improvements in Private Residential Development
}

\author{
Lawrence W.C. Lai* \\ Daniel C.W. Ho \\ K.W. Chau \\ Mark H. Chua
}

Preprint version of the paper accepted for publication in the

\section{Land Use Policy}

Suggested Citation

Lai, L. W. C, Ho, D. C. W, Chau, K. W., \& Chua, M. H. (2016). Repeated planning applications by developers under statutory zoning: A Hong Kong case study of delays and design improvements in private residential development. Land Use Policy, 57, 709-718.

DOI:10.1016/j.landusepol.2016.06.031

Corresponding Author:

Lawrence W. C. Lai

Ronald Coase Centre for Property Rights Research

The University of Hong Kong

Pokfulam Road

Hong Kong

Email: wclai@hku.hk 


\title{
Repeated Planning Applications by Developers under Statutory Zoning: a Hong Kong Case Study of Delays and Design Improvements in Private Residential Development
}

\author{
Lai, Lawrence, W. C., Ho, Daniel, C. W., Chau, K. W., \& Chua, Mark, H \\ Ronald Coase Centre for Property Rights Research, The University of Hong Kong
}

\begin{abstract}
Delays in obtaining development approvals have been advanced as a major reason for shortages if not also increase in cost of housing. This paper is the first systematic attempt to examine whether the apparently long period of time taken to obtaining statutory planning permissions by developers for major development projects under Comprehensive Development Area (CDA) zoning is due to Town Planning Board rejections or developers' strategy to hoard land or improve building design. Publicly available Town Planning Board data obtained from the Planning Department, property transaction records kept by the Land Registry, property market statistics released by the Rating and Valuation Department and macro-economic data from the Census and Statistics Department are used to find out the number of planning applications and time taken for a real estate project in a CDA zone involving residential components to start construction from the date of the first valid planning application as the means to ascertain if any delay in development was due to business innovation in building design to cater to sustainable development; or strategic behaviour to hoard land.
\end{abstract}

\section{Keywords}

Zoning, delay in development, housing supply, hoarding, innovations 


\section{Introduction}

The actual time taken for private development to complete for any planning jurisdiction, not to mention international comparison, is a much wanting land use policy and commercial information. ${ }^{1}$ The time involved is often asserted based on personal experience or hearsay, exaggerated in directions depending on the ideological preferences of the commentator. After all, the transaction costs of gathering reliable and publicly available information about such time are phenomenal. However, a good can be found in the literature. In Houston, USA, it takes only 120 days to "purchase land, obtain all the permits, build and move in" (O'Toole 2014: p.182). Surely the high-rise "starchitecture" of 50 -storey gated residential buildings in Hong Kong take at least one year to build, yet it would be alarming to find that in this metropolis famous for its nominally laissez faire economy, a development by a major developer may take over 15 years to complete. The benchmark time for a Hong Kong high rise property development is three years, which is the norm for a development subject purely to a land lease ("Government Lease," previously "Crown Lease") or obtained through a government land auction of leasehold interests.

This paper examines whether the apparently long period of time used in obtaining statutory planning permissions by developers for major development projects under Comprehensive Development Area zoning, which is almost synonymous with the zoning of a major real estate project subject to both a statutory zoning plan and the need to negotiate over a new lease rather than buying one in an auction, is due to Town Planning Board rejections or developers' strategy to delay or improve building designs from the point of view of sustainable development driven by business innovations.

\section{Theoretical Background}

There is a growing body of knowledge on the effect of delays in development approvals and housing prices. Normally, planning delays are associated with restrictions in housing supply (Cheshire et al. 2012, Ball 2011), which may, in turn, affect housing prices.

In their work, Mayo and Sheppard (2001) studied how "randomness" on the part of development control influences housing supply. Randomness is derived from developers' uncertainties over whether the authorities would grant them planning permission or how much time would be needed for the permission to be obtained. Gallent and Carmona (2004) also noted that the discretion of planning authorities in the decision-making process can contribute to planning delays. Staley (1994) had the same view and an empirical question to address here is whether rejection by a planning authority is actually the main cause of a lengthy process of development for major residential projects. Accordingly, Mayo \& Sheppard (2001) found that "stochastic" development control renders new housing supply more inelastic (also Cheshire et al. 2012). Specific to delays, they found that:

The supply of housing in the current period was shown to be adversely affected by an increase in the maximum possible planning delay, by a decrease in the minimum possible planning delay, or by an increase in the variance of possible planning delays (Mayo \& Sheppard 2001: p.125).

\footnotetext{
${ }^{1}$ In Malaysia, development approval time was about "one to two years" (Ting et al 2007: p.1). However, there was no information about how much time is taken after approval is obtained.
} 
However, although planning delays in themselves are not conceptually hard to measure, they are actually seldom measured. But there are some good exceptions. Delays are affected not just by the bureaucratic or administrative system itself, but also by the behaviors of the different actors involved (Monk \& Whitehead 1999). Among other factors, a lack of agreement between some planning agencies or between planners and developers over design and density standard issues can also further planning delays (Gallent \& Carmona 2004). It is not just a matter of measuring the length of time it takes for a single planning application to be processed, which can be controlled and limited by cut-off dates or penalties for lags, as one still has to consider the possibility of a series of applications for a single project. In their study, Ball, Allmendinger, \& Hughes (2009) measured the delay not per single application, but by project site. They focused on sites done only in one year to lessen other elements that affected the granting of a planning permission, but they excluded pre-application negotiations to simplify their study. Examining planning applications by project site is more useful for analysis because this considers multi-application projects that demonstrate, more directly, the effects of planning delays on a project's implementation (Ball, Allmendinger, \& Hughes 2009).

Aside from the arduous task of identifying and gauging planning delays, it is harder to identify and measure the costs they cause (Keogh \& Evans 1992). There lies an interplay between the costs and benefits of the planning system that contributes to the complexity of estimating the consequent private cost to developers and social cost to the immediate environs (Keogh $\boldsymbol{\&}$ Evans 1992). Differences in perspective over planning delays are also evident. For example, many builders see delays as problematic, while some planners see it as the "price of a democratic service" (Gallent \& Carmona 2004).

Amid this muddle in appreciation of planning delays and their costs, it is not just an issue of planners oppressing builders and developers. Monk and Whitehead (1999) pointed out that "landowners can exploit any oligopolistic certainty created by the planning system to delay the release of their land until prices have risen in the face of rising demand for housing." Intentional delays by builders or developers to gain some strategic advantage is not impossible. However, there has been no direct attempt to relate the delays to the possibility of voluntarily slowing down development to raise prices or institute environmental improvements. In the footsteps of Ball (2011) and Ball, Allmendinger, \& Hughes (2009), who dwelled on the applications of individual projects, this study tries to fill this research gap by systematically examining certain Hong Kong real estate developments.

\section{Social and Theoretical Background}

Delays in obtaining planning permissions as an important type of development approval other than building permissions and lease modifications have long been suspected of being and advanced as a reason for shortages in housing in Hong Kong, but this has never been verified by an in-depth investigation of the actual processing of individual applications. The Lands Department announced a standard of about one year. This paper is the first systematic attempt to examine whether the apparently long periods of time taken to obtain statutory planning permissions by developers for major development projects under Comprehensive Development Area (CDA) zoning were due to Town Planning Board (TPB) rejections or developers' strategy to hoard land or improve building designs. Unlike local councils in Western democracies, the TPB is not a democratically elected body, but a government-appointed body tasked with governing planning approvals for all of Hong Kong under the Town Planning Ordinance. 
Under Hong Kong's leasehold system, a change in use approved by the TPB cannot proceed to an application for building approval if the use is not permitted by the land lease. A modification of the lease and payment of a modification premium, a lengthy private negotiation process that takes about 350 days to complete for a normal case, is standard practice. (Lai et al. 2010)

The justification for a statutory planning control system is to screen development proposals so that only those that do not negate the objectives of the statutory plans can be carried out by developers. The screening is usually done by a board that comprises members (who are all appointed in the case of the Hong Kong) of the public who represent the public interest. This institutional arrangement has attracted two complaints by pro-market theorists.

The first complaint is that such a system would degenerate into a "planning game" that involves parties who are not concerned with the need for development, slows down or even frustrates development, and, therefore, increases the real cost of development and property prices (Staley 1994). The time it takes a developer to get development approval for its application is the main concern of the pro-market group.

The second, and more sophisticated, criticism is that this system has become more elaborate in terms of requirements (concurrence of government departments, impact assessments, public information, consultation, participation, and objection) and tends to favour larger developers, as they are more resourceful in terms of financing and technical knowledge to endure the scrutiny by public opinion. This would drive out smaller builders and create industrial concentration characterized by the presence of big developers. Consider this criticism of the land administration of lease modifications in Land and the Ruling Class in Hong Kong:

Through the workings of the lease modification system, developer conglomerates that acquired utility or public service companies have been able to exploit land assets in those companies. Idled utility sites or public bus depots have been converted into lucrative residential or commercial properties via using that system. This brings out the question of social justice and efficient use of land, the single most valuable natural resource that Hong Kong possesses (Poon 2005: p.111).

Poon's idea promoted a kind of conspiracy theory of collusion between government officials and business. This was put into proper perspective by the findings in a research project in relation to franchised public bus depots (Lai et al. 2013; Lai and Kwong 2015).

Poon did not point out that in addition to taking over public utility companies with land holdings, these consortia have also acquired agricultural land in the New Territories with a view towards urban and suburban development. As the typical formerly agricultural sites acquired by these developers are huge, they are usually zoned "Comprehensive Development Areas" (CDA) for better planning purposes.

This paper explores a new angle of looking at the behavior of developers during development approval procedures by a planning board, the Town Planning Board (TPB) of Hong Kong, by 
investigating the phenomenon of repeatedly made fresh applications by developers whose applications have already been approved. The de jure planning authority is the TPB, but the Director of Planning wields great influence within the Board. The theoretical interest lies in the fact that just as developers were found to have, by-and-large, voluntarily complied with planning conditions in the absence of statutory sanctions or even lease controls (Lai et al. 2007a). It may well be that developers were being innovative in making fresh applications in response to comments by the public and/or government departments. On the other hand, they might have also voluntarily "delayed" their projects by fresh applications. This articulates with the conjecture that developers engage in "rent-seeking" attempts by raising the entry costs of competition to deter rivals.

Lai and Ho (2008) discovered an interesting phenomenon: developers who obtained TPB approvals for their projects often made new applications for the same sites. From the perspectives of the planning officers involved in these fresh applications, they are attempts to "test the limits" of the planning, environmental, engineering, and other officers who advise the TPB. From the government angle, this practice creates a lot of work for the planners and there has been a Bill to charge developers for planning applications, as in the case of building applications under the Buildings Ordinance. This Bill has, hitherto, not been approved by the Legislative Council. However, from the point of view of the applicant, this is a statutory right to achieve a higher value outcome. From an economic perspective, this can be interpreted as either a profit-seeking "strategic behavior" or a genuine and socially beneficial knowledge discovery process, which takes time, to achieve a higher value outcome. The former may be purely testing the limits or delaying development in time of uncertainty. The latter, which is far more significant, involves innovations and qualitative changes to the proposals.

This paper is the first systematic study on the nature and patterns of the repeat applications for private residential development within Comprehensive Development Area (CDA) Zones (Lai 1996, 1998; Lai et al. 2007a, Lai et al. 2007b; Lai et al. 2009) with a view to verifying if developers innovate during the development control process by meeting the following objectives.

In terms of development control research using non-aggregate data, this paper project is a new endeavour, as the extant literature is dominated by attempts to model the regulator's behaviour (for instance, Tang and Tang (1999); Tang and Choy (2000), Tang, Choy and Wat (2000); Lai and Ho (2001a, b, c, d; 2002a, b, c; 2003); Chau and Lai (2004); and Lai et al. (2011)), rather than that of the regulated (except Lai et al. 2008).

\section{Theoretical and Public Policy Significance}

Theoretical Significance

Capitalizing on the availability of non-aggregate development control data for statutory planning in Hong Kong, this paper is a novel approach to verify the conventional libertarian belief that a planning regime delays development. Furthermore, it is the first attempt to investigate if development controls can stimulate innovations as a means to create new values 
under trial by a planning board. Schumpeterian innovations are essential for sustainable development (Yu et al. 2000; Lai and Lorne 2003, 2006, 2015).

\section{Policy Significance}

This paper is of great policy significance, as it should provide much wanted information backed by reliable statistics to inform policymakers regarding the behaviour of developers under the present planning regime. In particular, the question of if there really were attempts by developers to abuse the system, hitherto un-surveyed, can be properly addressed. Besides, whether or not the "Hong Kong Model" of the Hong Kong Special Administrative Region Government for sustainable development stresses economics, society, and the environment (Lai et al. 2006) can also be probed.

This paper covers three basic areas of public policy and theoretical concern (Figure 1), namely developer's strategy, business innovations in real estate, and statutory planning control.

The first theoretical concern is economic: it concerns the strategic behaviour of developers that use their land banks, which pertains to such contentious policy issues as the social costs of suspected land hoarding.

The second concern is the question of the possibility of sustainable development via business innovations, which transforms negative externalities into positive ones (Lai and Lorne 2006, 2015).

The third concern is the operation of the statutory planning system in rationing redevelopment rights, which, in the case of Hong Kong, means, on the one hand, an additional hurdle to redevelopment, according to a Crown/Government Lease, and, on the other hand, a possible means to promote sustainability via participation by stakeholders.

The looming criticism of developers in relation to the use of land banks should not be taken into isolation but interpreted from a public policy development point of view of the wider constitutional context of post-colonial Hong Kong which is witnessing "rising public mistrust of the government and intensifying grassroots grievances" (Lau and Kuan 2000: p.1024). It is hoped that our project would provide the public and policy makers a better informed picture of a key dimension of everyday life in Hong Kong - housing supply.(Lai and Ho 2008; Lai et al. 2010).

\section{Figure 1 about here}

The local public policy significance of this project should be viewed in light of a certain kind of public opinion with a sentiment that is highly critical of developers as anti-social oligarchs controlling the economy and helping to drive up property prices. It so happens that these developers are also members of consortia that hold key public utilities (with land assets for plants) protected by the government under legislation and franchised conditions. Several opinion groups (such as "Myradio" and "Left 21") have criticized the Town Planning Board for favouring large developers. Their views were certainly conjectural, but there is a need to rigorously investigate how this relates to property development. Partly this was evaluated in Lai et al. (2013) and Lai and Kwong (2015) in relation to bus depot allocations. This paper will directly examine developers' behaviour in one of the three major development application processes, statutory planning, in Hong Kong. 
The idea of unifying these concerns is sustainable innovation in real estate development. The presence or absence of such innovation can be empirically determined by ascertaining if there is any actual sustainable innovation in real estate development projects as a consequence of public or departmental comments during the statutory planning process. This idea is not hard to test, as all comments on planning applications by the public and members of the Town Planning Board and changes in planning proposals after 9 June 2005 (per Gazette Notice L.N. 50 of 2005) can be inspected at the Planning Department.

\section{Institutional and Geographical Background}

Until the end of the Second World War, urban Hong Kong consisted essentially of Victoria City (from Kennedy Town to Wanchai), and Kowloon Peninsula north to Boundary Street. Most of the rest of Hong Kong Island, New Kowloon, and the New Territories were suburban or rural. The CBD was then in Central. Since the 1950s, the new town policy has decentralized the city's population, even though the country parks (designated in the 1970s) have remained non-urban (Lai 1999)

It is well-known that property prices in Hong Kong have been very high since the 1980s. Many blame the government as a land monopoly for maintaining a high land price policy by restricting the supply of leasehold interests via auctioning. Researchers have found this as a means of indirect tax (Jao 1976) to keep direct tax as low as $15 \%$ for income and profit and for social redistribution (Lai 1984). The housing situation, however, has been complicated: mMore than $50 \%$ of the population are housed by the state in well-planned and cheap public housing estates. Land supply for new housing in Hong Kong has traditionally come from four sources:

(a) reclamation from the sea;

(b) terracing of hills;

(c) redevelopment of leasehold land by developers; and

(d) the redevelopment of public housing estates by the state.

Sources (a) and (b) are somewhat like "greenfield sites" controlled by the state, whereas (c) and (d) are "brownfield sites". Source (d) is not for private housing. By tradition, Source (a) is the prime mover of land production for private and public development (Lai and Baker 2014; Lai et al. 2014).

Private development under Hong Kong's leasehold land system must follow the land use and development parameters contractually agreed to between the state and the lessee by a civil contract in the form of a deed or "government lease" (Lai 1998; and Lai et al. 2010). If the lessee wants to increase the rights or reduce some development restrictions, s/he must negotiate with the Lands Department for a "lease modification" and pay a modification premium. Statutory zoning imposed unilaterally by the state may enlarge, but usually attenuate/remove, the contractually agreed-upon rights under a government lease. Zoning (as a matter of "development control") restricts supply by adding an extra hurdle to development in case it attenuates the rights under the lease, who must win them back through a planning application, which is also an essential prelude to lease modification. However, the real cause of high property prices (Chiu and Chau 2005) nowadays is a combination of strong demand by wealthy Mainland Chinese investors, which led to the announcement in 2012 of the 
protectionist policy "Hong Kong Property for Hong Kong People"2, and the post-colonial government's neglect of "forward planning," or the production of (a) and (b) with the demise of the Strategic Planning Unit (Lai et al. 2014). The only source of new land supply for private housing is Source (c) and CDA zones in the New Territories are a major component of this source.

A typical CDA project does not begin with the developer buying land from a government land auction, but through land acquisition from landowners. Figure 2 compares the procedure of development from land purchase to occupation for a typical CDA project to that for a nonCDA project, which requires planning permission. Lease modification is important if the use applied for, whether under CDA zoning or not in the statutory town plan, is not permitted by the government lease. Generally, development on land purchased directly from the government requires no lease modification.

Figure 2 about here

\section{Research Objectives and Hypothesis}

The general objective of this paper is to find out the number of planning applications and time taken for a real estate project involving residential components in a Comprehensive Development Area zone to start construction from the date of the first valid planning application as the means to ascertain if any delay in development was due to business innovation in building design to cater to sustainable development or strategic behaviour to hoard land. The general objective was to achieve four information search exercises.

S1: find out the exact number of planning applications involved for each CDA project before they started construction from the date of the first valid planning application made after 1 January 1990 to 31 October 2014, with the effective date of the amendment to the Town Planning Ordinance (10 June 2005) falling in the middle;

S2: find out the exact amount of time (in months) that involved all planning applications for a CDA project to start construction with all dates matching those in $\mathrm{S} 1$;

S3: find out if the developer's amendments to the planning proposals involved innovations for each CDA project to start construction with all dates matching those in S1; and

S4: find out if the time taken by a developer to get final planning permission to commence construction was statistically related to the size of the proposed development site and/or the environmental condition of the district in question.

The data for S1 and S2 were obtained from the Planning Department's website, while those for $\mathrm{S} 3$ were obtained from its public enquiry service.

\footnotetext{
2 LCQ5: The "Hong Kong Property for Hong Kong People" policy. http://www.info.gov.hk/gia/general/201406/11/P201406110675.htm
} 
The general refutable hypothesis for this fact finding exercise is that the TPB was the major cause of delays in residential CDA projects. This hypothesis would be rejected if there is good evidence that developers tend to make fresh applications after they obtain planning permissions.

\section{Findings}

First, there were a total of 261 property development projects within CDA zones that included sites for residential use, ${ }^{3}$ for which the first planning applications were made before 10 June 2005 and 94 projects for which first applications were made after 9 June 2005. Of the former, only $\underline{65}$ were fully or partly-completed ${ }_{-}^{4}$ for residential purposes by 31 January 2015 . Table 1 presents the key features of these 65 projects with their development names, lot numbers, and addresses suppressed ${ }^{5}$. These features, which inform on the length of time expended in the planning application sequences, gross floor area, and gross site area, are pertinent to an adequate assessment of the impact of the projects on total housing supply.

\section{Table 1 about here}

Second, a simple linear regression test was conducted with the 65 fully or partially completed sites and it established that the correlation between the length of time and the size of a site was weak and insignificant. Tables 2 and 3 show the results of the linear regression from the length of time between the first application and the Planning Department to the granting of the first Occupation Permit versus the Gross Site Area and Gross Floor Area, respectively. Tables 4 and 5 are similar to the previous two tables, but use the length of time from the first successfully approved planning application. All four cases show that the length of time and the size of the sites are weakly-correlated. That is, the size of the CDA site does not affect how long it would take to complete a project starting from the planning application stage.

\section{Tables 2, 3, 4 and 5 about here}

Third, the exact amount of time (in months) that involved all planning applications for every CDA project that started construction from the date of the first valid planning application was identified. Figure 3 presents a sample morphology of the planning applications of 7 of the lengthier completed projects. They generally did involve TPB frustrating the projects but a consecutive series of "conditional approvals" (indicated by the notation $\mathrm{C}$ ) or unconditional approvals (A). Branching of application strings is also an interesting feature reflecting some strategic project management measure. All in all, the long time taken was not due to TPB standing in the way blocking development refusing to grant planning permissions but developers own reapplications.

\section{Figure 3 about here}

Fourth, a more rigorous test on the decision factors of TPB, non-aggregate planning statistics for all residential sites of the $261 \mathrm{CDA}$ sites by a probit regression model established that a site in the New Territories (in contrast from Kowloon or Hong Kong Island) and a site situated in

\footnotetext{
${ }^{3}$ Such uses as open storage and parking vehicles were excluded.

${ }^{4}$ Because of their irrelevance to the housing supply, sites with their first planning application before the Town Planning Ordinance Amendments on 10 June 2005 not partially or fully completed were excluded.

${ }^{5}$ For details statistical analysis, see Lai (etal 2015).
} 
an area with more developmental components (as a measure of development density if not also perceived marginal cost of development) was statistically less likely to get approved in the first instance of the first application. Gross floor area was insignificant as a major consideration by the TPB for a first application.

The model was used in similar studies of the TPB by Lai and Ho (2001a, b, c, d; 2002a, b; 2003) and Chau and Lai (2004) using Equation (1) below.

$p\left(x_{\alpha 1}, x_{\alpha 2}, \ldots, x_{\alpha j}\right)=\mathbf{F}\left(\beta_{0}+\beta_{1} x_{\alpha 1}+\cdots+\beta_{j} x_{\alpha j}\right)=\frac{1}{\sqrt{2 \pi}} \int_{-\infty}^{\beta_{0}+\beta_{1} x_{\alpha 1}+\cdots+\beta_{j} x_{\alpha j}} \exp \left(\frac{-t^{2}}{2}\right) d t(1)$

Or equivalently:

$\mathbf{F}^{-1}\left[p\left(x_{\alpha 1}, x_{\alpha 2}, \ldots, x_{\alpha j}\right)\right]=\beta_{0}+\beta_{1} x_{\alpha 1}+\cdots+\beta_{j} x_{\alpha j}(2)$

The probability of a successful first-instance planning application was modelled as a function of whether or not a site is in the New Territories, how high is the development density of the proposed project, and its proposed GFA. $\mathrm{x} \alpha 1, \mathrm{x} \alpha 2, \ldots, \mathrm{x}$ aj are the values taken by these variables for the $\alpha$ th first-instance planning application. To estimate the parameters $\beta_{0}, \beta_{1}, \ldots$, $\beta_{\mathrm{j}}$, the maximum likelihood method was applied.

Only the cases of the very first-instance of application for each site were utilized because such applications were the most likely to display the above factors, which are also the most relevant during the Planning Department's evaluation. Moreover, the succeeding applications are normally general or partial updates of the previous ones. For initially denied applications, the first succeeding instances in which they are approved were also included in the observation to see how the decisions were affected by any change in these factors, if applicable. A total of 163 applications were used.

The statistical details of the tests are presented in Appendix 1.

Fifth, there was no evidence of any major planning innovation involved in the proposals submitted in the fresh applications made after a planning permission was granted. However, there was evidence of some gradual improvements in the landscape and building design. The team inspected the earliest MLPs and their respective latest MLPs available for public inspection in the Planning Department. The actual architectural drawings and schedules of accommodation were then compared. If a site had many sub-components or phases, the earliest and latest of a particular phase or sub-component were inspected. Some sites only had one MLP deposited with the Planning Department, so no comparison could be made for these cases. Most changes in MLPs upon re-application were of minor design significance, which reflected changes in the market conditions (say, from larger flats to smaller flats or vice versa) rather than perceptible revisions in planning or design philosophy. Among the major changes found in some fresh applications, part of the gross floor areas originally planned for office spaces or hotels in three cases were converted to residential in the later designs. Also, for at least two sites the footprints and shapes of the buildings were reconfigured in subsequent MLPs. As expected, the latter MLPs generally contained more details of the landscaping and recreational facilities. It is worth noting that these few cases of larger changes were a relatively small fraction of the MLPs inspected and generally trended towards more superior designs. 
Sixth, there was no evidence that the time required for a lease modification was a major cause of a re-application. Although the actual time taken to obtain a lease modification was secret, no rational developer applied for lease modification until planning permission for a site's intended use was obtained. The time gap between the first successful planning application and the execution of the lease modification document for each of the 65 cases was calculated. The average time gap found was three years, which was longer than the norm for the Hong Kong real estate market, not to mention for the Lands Department's service pledge to complete the process within one year.

Seventh, as far as land supply is concerned, the number of private housing units generated by the (65) projects built amounted to less than $50 \%$ of all approved quantum, if not all CDA. Had all the unbuilt CDA zone projects (whether pending or stopped) been used to develop housing - according to Hong Kong's new town density planning standards of 2,300 persons per hectare, ignoring large site reduction factors, then as many as a million people could be housed.

\section{Discussion and Conclusion}

Traditional libertarian analyses of development control typically criticizes the development control authority as the culprit for delays in development and escalations in housing costs. This paper is original as the first in-depth empirical study of the morphology of development approvals and voluntary delays in the actual development of the development control process. The cases examined were major development projects controlled by government-approved master layout plans submitted by developers to the TPB. While some marginal improvements to design were found among the resubmitted master layout plans, no significant trend of innovation was discerned and all adjustments by developers were due mainly to their responses to changing market conditions rather than to the size of the development project. Significant delays were found. Whether or not these were compensated by better-valued properties is a separate matter, but there is a prima facie case for policymakers to look into the phenomenon of repeatedly made fresh development applications though permissions have already been granted with a view to speeding up the development process. The TPB was not the principal cause of delay as it did not appear that it was very difficult for developers to get planning permissions or even lease modifications.

In this study we did not identify or disclose the developers of individual projects, though it is locally well-known that "the Big Four" would be involved. Our study focused on the phenomenon of the strategic behaviour of developers and the need to speed up the development of CDAs rather than on who should take the blame for lengthy period of (if not delay in) development, although the Planning Department hardly escapes criticism for not being sensitive to or aware of the situation and, above all, for neglecting forward planning to produce new land for sale by reclamation.

Note that as far as innovation was concerned, the focus was not on whether there was any innovation by a project, but whether the fresh MLPs reflected any major innovation. We inspected and compared the publicly available MLPs of 65 built projects and found little evidence of great change.

A factor that may explain the voluntary withholding of the exercise of the planning permissions by developers that is beyond the scope of this study is the transaction costs required to acquire titles of land under fragmented ownership. The developers may very well start the process for 
obtaining development approvals while, jumping the gun, attempting to acquire all property titles to allow the commencement of the construction projects. As they are still struggling in land assembly, they are compelled to make fresh MLP submissions to keep the planning permissions alive and take the opportunity fine tune the projects in response to market changes. This possibility is an area worth investigating.

It is hoped that this paper, as a demonstration case study, would stimulate further and better inquiries into the strategic behaviour of developers that time their construction processes, which has social implications for housing. We also hope that our work, constrained by resources, will kindle an interest in international comparisons of developers' strategic behaviour and property rights constraints.

\section{Acknowledgements}

The authors acknowledge the funding support for this project by the Central Policy Unit Grant No. CPU (2013.A8.014.14C). They also deeply appreciate the useful comments and questions raised by the two anonymous referees for the manuscript. 


\section{Appendix 1: Details of probit analysis}

Table 6 shows the statistical characteristics of the 3 decision variables "location" (whether New Territories or not) "gross floor area", and "development density" of each application. Table 7 shows the results of the Probit model regression using Eviews8. NT refers to whether or not the site was in the New Territories (1 if yes or 0 if not). This distinguished whether or not it was more difficult for sites in more urbanized areas to get their first applications approved. DEVDENS is the development density of the proposed CDA site. This is the gross floor area over the site area. LOGGFA is the logarithm of the proposed gross floor area.

\section{Tables 6 and 7 about here}

The results showed that only NT and DEVDENS had $p<0.05$, which were significant. The positive sign in the coefficient of NT meant that a site in the New Territories (in contrast to Kowloon or Hong Kong Island) was more likely to be approved in the first instance of its first application. On the other hand, the negative sign in the coefficient for DEVDENS meant that as more developments were proposed for a given unit site area, the greater their chances of rejection. The results, with respect to the gross floor area, were not significant. It seemed that it was not a major consideration for the first application. 


\section{References}

Ball, M. (2011), "Planning Delay and the Responsiveness of English Housing Supply," Urban Studies, Vol.48, No.2, pp.349-362.

Ball, M., Allmendinger, P., and Hughes, C. (2009), "Housing Supply and Planning Delay in the South of England," Journal of European Real Estate Research, Vol.2, No.2, pp.151-169.

Chau, K.W. and Lai, L.W.C. (2004), "Planned Conversion of Rural Land: a Case Study of Planning Applications for Housing and Open Storage Uses in Agriculture Zones," Environment and Planning B: Planning and Design, Vol.31, No.6, pp.863-878.

Cheshire, P.A.U.L., Leunig, T., Nathan, M., and Overman, H.E.N.R.Y. (2012), Links between Planning and Economic Performance: Evidence note for LSE Growth Commission.

Chui, L. H. T., and K. W. Chau (2005), "An empirical study of the relationship between economic growth, real estate prices and real estate investments in Hong Kong." Surveying \& Built Environment pp. 19.

Gallent, N. and Carmona, M. (2004), "Planning for Housing:

Unravelling the Frictions in Local Practice," Planning Practice \& Research, Vol.19, No.2, pp.123-146.

Jao, Y. C. (1976), "Land use policy and land taxation in Hong Kong." The Cities of Asia: A Study of Urban Solutions and Urban Finance Singapore University Press for the Economic Society of Singapore, pp. 277-303.

Keogh, G. and Evans, A.W. (1992), "The Private and Social Costs of Planning Delay," Urban Studies, Vol.29, No.5, pp.687-699.

Lai, L.W.C. (1984), Review on Rosanna Chan's “An Anatomy of the Failure of Hong Kong Government's Announced 10 Years Public Housing Plan in 1972," Asian Journal of Public Administration, Vol.6, No.2 (December, 1984), pp.227-230.

Lai, L.W.C. (1996, 1998), Zoning and Property Rights: a Hong Kong Case Study. Hong Kong: Hong Kong University Press.

Lai, L.W.C. (1999), "Reflections on the Abercrombie Report 1948," Town Planning Review, Vol.70, No.1, pp.61-87.

Lai, L.W.C. (2003), Town Planning in Hong Kong: a Review of Planning Appeal Decisions 1997-2001. Hong Kong: Hong Kong University Press.

Lai, L.W.C. and Baker, M. (2014), "The Final Colonial Regional Plan that Lingers on: Hong Kong's Metroplan,” Habitat International, Vol.44, pp.216-228.

Lai, L.W.C. and Ho, D.C.W. (2008), The Development Approval Process in Hong Kong, Hong Kong: Bauhinia Foundation Research Centre. 
Lai, L.W.C. and Ho, W.K.O. (2001a), "Small is Beautiful: a Probit Analysis of Planning Applications for Small Houses in Hong Kong," Environment and Planning B: Planning and Design, Vol.28, No.4 (2001), pp.611-622.

Lai, L.W.C. and Ho, W.K.O. (2001b), "A Probit Analysis of Development Control: a Hong Kong Case Study on Residential Zones," Urban Studies, Vol.38, No.13 (December), pp.24252437.

Lai, L.W.C. and Ho, W.K.O. (2001c), "Zone Separation: A Probit Analysis of Hong Kong Planning Application Statistics," Environment and Planning B: Planning and Design, Vol.28, No.6, pp.923-932.

Lai, L.W.C. and Ho, W.K.O (2001d), "Low-Rise Residential Developments in Green Belts: A Hong Kong Empirical Study of Planning Applications," Planning Practice and Research, Vol.16, No.3/4, pp.321-335.

Lai, L.W.C. and Ho, W.K.O. (2002a), "Planning for Open Storage of Containers in a Major International Container Trade Centre: a Quantitative Analysis of Hong Kong Development Control Statistics," Environment and Planning B: Planning and Design, Vol.29, No.4, pp.571587.

Lai, L.W.C. and Ho, W.K.O. (2002b), "An Econometric Study of the Decisions of a Town Planning Authority: Complementary \& Substitute Uses of Industrial Activities in Hong Kong," Managerial and Decision Economics, Vol.23, No.3, pp.121-135.

Lai, L.W.C. and Ho, W.K.O. (2002c), "Using Probit Models in Planning Theory: an Illustration," Planning Theory, Vol.1, No.2, pp.146-162.

Lai, L.W.C. and Ho, W.K.O. (2003), "Modeling Development Control of Residential Development: A Probit Analysis of Rent Seeking and Policy Autonomy in Town Planning in Hong Kong in Columbus, Frank (ed.), Politics and Economics of Asia, Vol.VII, Asian Economic and Political Issues Vol.9, Nova Science Publishers, Ch.4, pp.155-176.

Lai, L.W.C. and Kwong, J.W.Y. (2015), "Hong Kong Land Policy for Bus Depot Allocation: a Valuation Analysis," Surveying and Built Environment, Vol.23, No.1, pp.23-55.

Lai, L.W.C. and Lorne, F.T. (2003 eds.), Implementing and Understanding Sustainable Development, New York, Nova Science.

Lai, L.W.C. and Lorne, F.T. (2006), "The Coase Theorem and Planning for Sustainable Development", Town Planning Review, Vol.77, No.1, pp.41-73.

Lai, L.W.C. and Lorne, F.T. (2013), "Transaction Cost Reduction and Innovations for Spontaneous Cities: Promoting a "Meeting" between Coase and Schumpeter," Planning Theory, published on line on 18 July 2013.

Lai, L.W.C. and Lorne, F. (2015), "The Fourth Coase Theorem: State Planning Rules and Spontaneity in Action," Planning Theory, Vol.14, No.1, pp.44-69. 
Lai, L.W.C., Ho, D.C.W., Leung, H.F. (2004, 2010), Change in Use of Land: a Practical Guide to Development in Hong Kong. Hong Kong: Hong Kong University Press.

Lai, L.W.C., Lorne, F.T. and Lu, W.W.S. (2014), "A Catallactic Framework of Government Land Reclamation: the Case of Hong Kong and Shenzhen," Habitat International, Vol.44, pp.62-71.

Lai, L.W.C, Chau, K.W., Ho, D.C.W. and Lorne F.T. (2006), “A Hong Kong” Model of Sustainable Development," Property Management, Vol.24, No.4, pp.16-18.

Lai, L.W.C., Yung, P., Li, R.Y.M. and Ho, D.C.W. (2007a), "The Private Supply of and Public Demand for Planning: Compliance with Planning Conditions in the Absence of Direct Statutory Enforcement Measures." Planning Policy and Research, Vol.22, No.4, pp.535-557.

Lai, L.W.C., Chau, K.W., Wong, W.S., Yiu, E.C.Y., Chan, P.Y.L., Wong, S.K. (2007b), "Measuring and Interpreting the Effects of A Public-Sector-Led Urban Renewal Project on Housing Prices: An Empirical Study of a Comprehensive Development Area Zone Developed Upon Taking in Hong Kong", Environment and Planning B: Planning and Design, Vol.34, No.3, pp.524-538.

Lai, L.W.C., Lam, G.C., Chau, K.W., Hung, C.W.Y., Wong, S.K. and Li, R.Y.M. (2009), "Statutory Zoning and the Environment: a Hong Kong Empirical Analysis of the Direct Effect of Zoning on the Environment and the Potential Contribution of Planning Conditions to Sustainable Development," Property Management, Vol.27, No.4, pp.242-266.

Lai, L.W.C., Wong, S.K., and Chau, K.W. (2011), "Are Engineering Reasons Zoning Neutral? An Empirical Inquiry into Development Proposals in Green Belts and Agriculture Zones," Environment and Planning B: Planning and Design, Vol.38, No.2, pp.322-337.

Lai, L.W.C., Chau, K.W., Kwong, J.W.Y., Ching, S.T., Cheung, P.C.W., and Lorne, F.T. (2013), "Acquisition and Redevelopment of Bus Garages: a Hong Kong Land Policy and Planning Case Study,” Habitat International, Vol.39, pp.75-84.

Lai, L.W.C., Ho, D. C.W., Chau, K.W., Chua, M. H. and Yu, R. K.K. (2015), "Repeated Planning Applications by Developers under Statutory Zoning: a Technical Note on Delays in Private Residential Development," Surveying and Built Environment, Vol.24, No. 1, pp. 8-36.

Lau, S.K. and Kuan, H.C. (2000), "Hong Kong's Stunted Political Party System." The China Quarterly Vol.172, pp.1010-1028.

Mayo, S. and Sheppard, S. (2001), "Housing supply and the effects of stochastic development control," Journal of Housing Economics, Vol.10, No.2, pp.109-128.

Monk, S. and Whitehead, C.M. (1999), "Evaluating the economic impact of planning controls in the United Kingdom: Some implications for housing," Land Economics, Vol.75, No.1, pp.74-93.

O’Toole, R. (2014), "Houston's Land-Use regime: a Model for the Nation," in D.E. Andersson and S. Moroni (2014 eds.), Cities and Private Planning: Property Rights, Entrepreneurship and Transaction Costs, Edward Elgar, pp.174-198. 
Poon, A. (2005), Land and the Ruling Class in Hong Kong. Hong Kong, Alice Poon.

Staley, S.R. (1994), Planning Rules and Urban Economic Performance: the Case of Hong Kong, Hong Kong, Chinese University Press.

Staley, S.R. (2001), "Ballot Box Zoning, Transaction Costs and Urban Growth,” Journal of American Planning Association, Vol.67, No.1, pp.25-31.

Tang, B. and Tang, R.M.H. (1999), "Development Control, Planning Incentive and Urban Redevelopment: Evaluation of a Two-Tier Plot Ratio System in Hong Kong," Land Use Policy, Vol.16, pp.33-43.

Tang, B. and Choy, L.H.T. (2000), "Modelling Planning Control Decisions," Cities, Vol.17, pp.219-225.

Tang, B., Choy, L.H.T. and Wat, J.K.F. (2000), "Certainty and Discretion in Planning Control: a Case Study of Office Decentralisation,” Urban Studies, Vol.37, No.13, pp.2465-2493.

Ting, K.W., Zhou, S.Z. and Bao, H.X.H. (2007), "Regional Variations of Residential Real Estate Returns in Malaysia," 12th Asian Real Estate Society Annual Conference, 9-12 July 2007, Macau Tower, Macau, China.

Yu, B.T., Shaw, D, Fu, T., and Lai, L.W.C. (2000), "Property Rights and Contractual Approach to Sustainable Development," Environmental Economics and Policy Studies, Vol.3, No.3, pp.291-309. 


\section{Figure 1: The Theoretical and Public Policy Concerns}

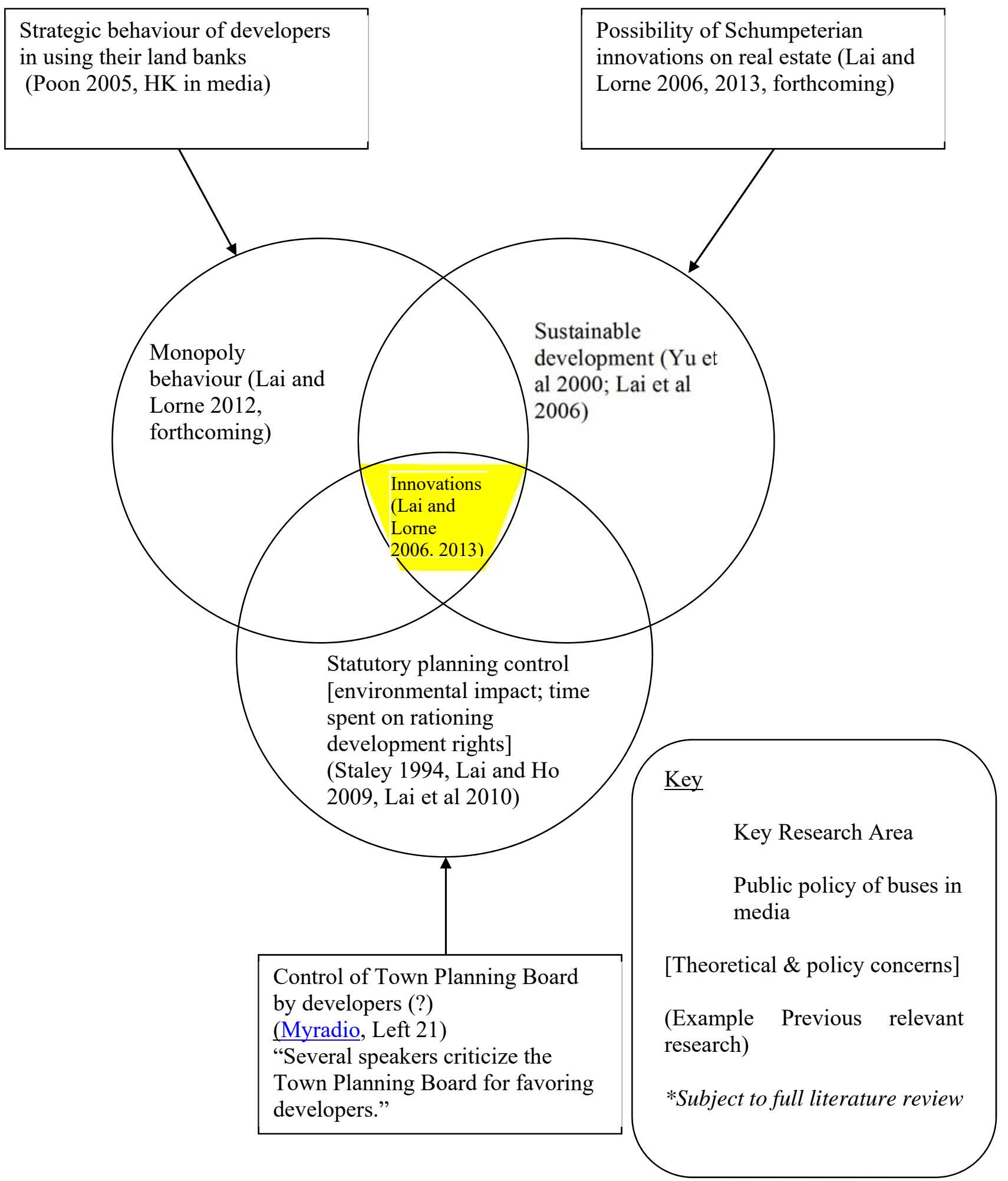




\section{Figure 2: Comparison of Non-CDA and CDA development processes}

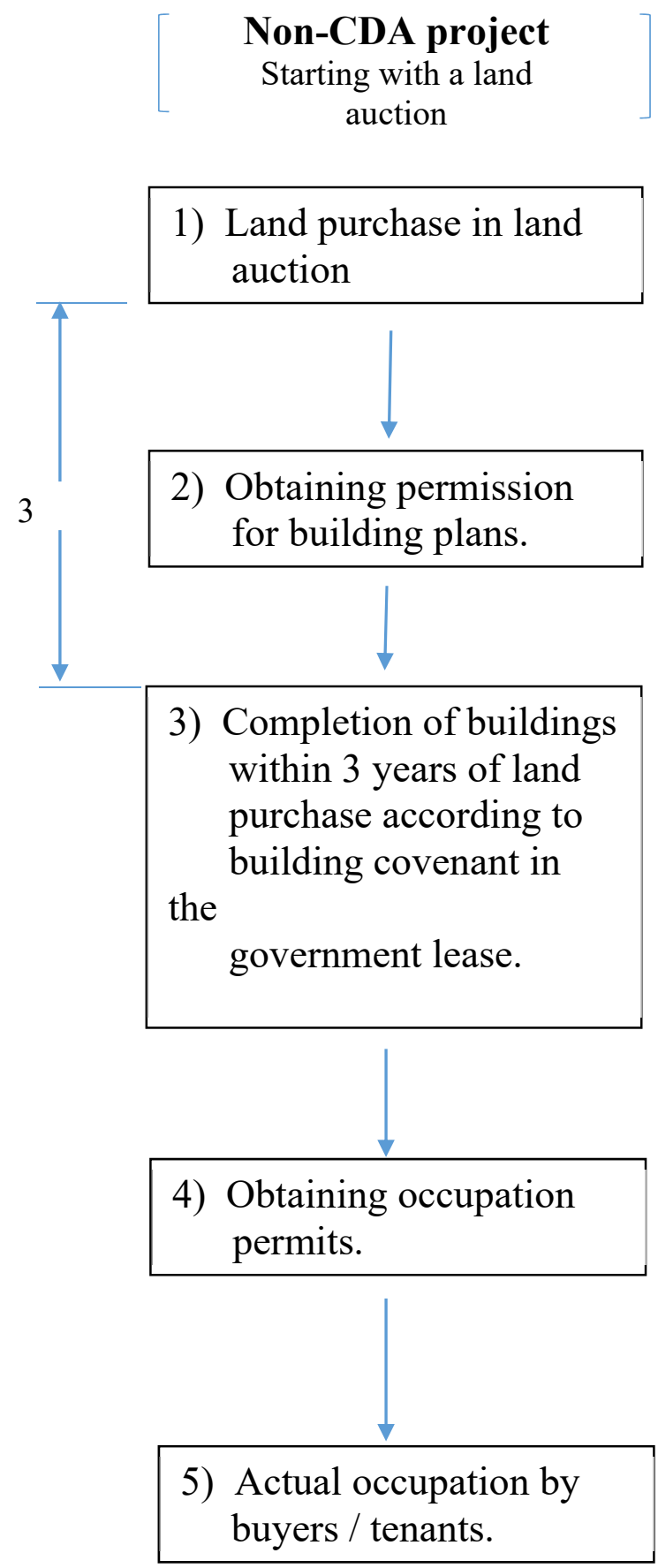

\section{CDA Project}

1) Land assembly of all land parcels in the CDA zone.

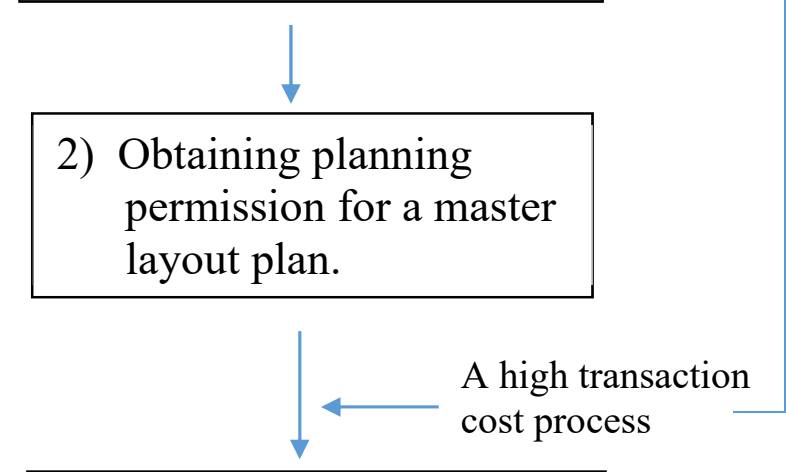

3) Obtaining lease modification if necessary.

4) Obtaining permission for building plans.

5) Completion of buildings.

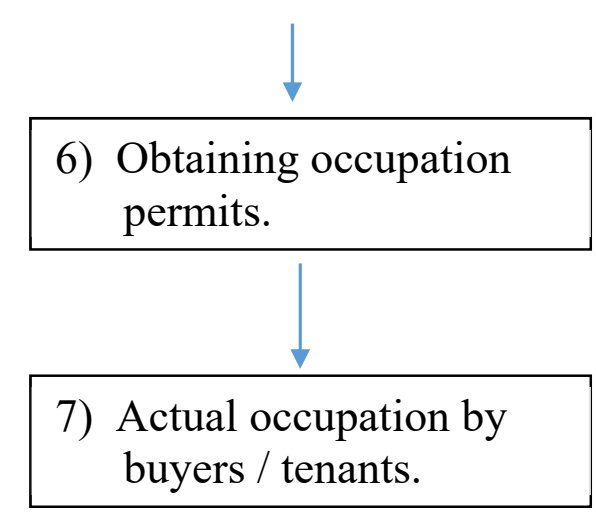




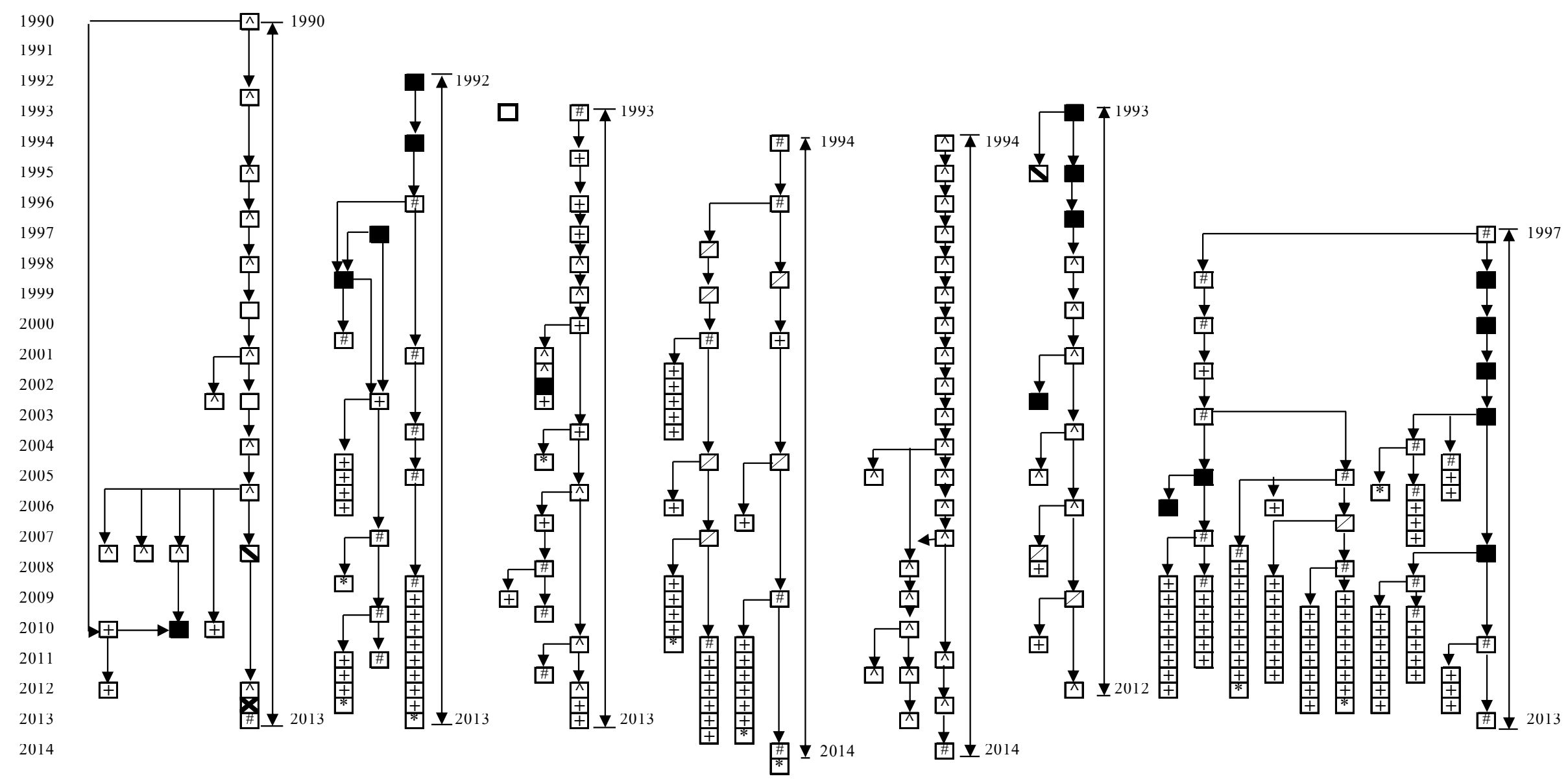

LEGEND

$\begin{array}{ll}\boxplus & \text { Approved } \\ \bigotimes & \text { Approved with condition(s) } \\ \boxplus & \text { Approved with condition(s) on a temporary basis }\end{array}$

$\square$ Revoked

$\boldsymbol{\nabla}$ Abandoned by appellant

\# Approved with condition(s) on a temporar

Rejected

$\square$ Deterred

区 Invalid

Figure 3: Seven Long and Complicated CDA Application Cases 
Table 1 Features of completed CDA sites

\begin{tabular}{|c|c|c|c|c|c|c|c|}
\hline Sites & $\begin{array}{c}\text { Time } \\
\text { from first } \\
\text { applicati } \\
\text { on to } \\
\text { date of } \\
\text { OP } \\
\text { (Months) }\end{array}$ & $\begin{array}{c}\text { Time from } \\
\text { first } \\
\text { successful } \\
\text { application } \\
\text { to date of } \\
\text { OP } \\
\text { (Months) }\end{array}$ & $\begin{array}{c}\text { Gross } \\
\text { Floor } \\
\text { Area } \\
\text { (hectares) }\end{array}$ & $\begin{array}{l}\text { Gross site } \\
\text { area in } \\
\text { first } \\
\text { approved } \\
\text { MLP } \\
\text { (hectares) }\end{array}$ & $\begin{array}{l}\text { Gross site } \\
\text { area in } \\
\text { last } \\
\text { approved } \\
\text { MLP } \\
\text { (hectares) }\end{array}$ & $\begin{array}{c}\text { Number } \\
\text { of flats in } \\
\text { earlier } \\
\text { approved } \\
\text { MLP }\end{array}$ & $\begin{array}{c}\text { Number } \\
\text { of flats in } \\
\text { last } \\
\text { approved } \\
\text { MLP } \\
\text { available }\end{array}$ \\
\hline 1 & 209 & 188 & 5.03 & 1.66 & 1.63 & 772 & 822 \\
\hline 2 & 192 & 190 & 0.58 & 0.28 & 0.22 & 34 & 36 \\
\hline 3 & 181 & 181 & 20.39 & 3.90 & 3.60 & 2,368 & 2,600 \\
\hline 4 & 180 & 164 & 8.36 & 2.00 & 2.00 & 1,904 & 1,466 \\
\hline 5 & 178 & 169 & 4.13 & 10.32 & 1.00 & 297 & 265 \\
\hline 6 & 166 & 162 & 7.48 & 0.80 & 0.80 & 896 & 924 \\
\hline 7 & 166 & 163 & 11.76 & 18.37 & 18.37 & 1,819 & 1,860 \\
\hline 8 & 158 & 158 & 13.22 & 5.00 & 5.00 & 662 & 662 \\
\hline 9 & 157 & 157 & 12.45 & 2.40 & 2.37 & 1,776 & 1,720 \\
\hline 10 & 154 & 95 & 3.15 & 1.50 & 1.40 & 750 & 800 \\
\hline 11 & 153 & 153 & 10.34 & 1.00 & 1.00 & 1,748 & 1,748 \\
\hline 12 & 145 & 106 & 13.47 & 1.30 & 1.30 & 1,000 & 1,136 \\
\hline 13 & 137 & 100 & 18.06 & 3.80 & 3.80 & 1,248 & 1,576 \\
\hline 14 & 136 & 136 & 5.43 & 0.60 & 0.20 & 1,412 & 1,400 \\
\hline 15 & 136 & 136 & 9.12 & 0.80 & 0.80 & N/A & N/A \\
\hline 16 & 135 & 135 & 0.77 & 1.29 & 1.34 & 50 & 87 \\
\hline 17 & 134 & 126 & 6.25 & 4.70 & 4.70 & 992 & 992 \\
\hline 18 & 133 & 129 & 8.72 & 3.82 & 3.84 & 1,216 & 1,264 \\
\hline 19 & 130 & 129 & 165.28 & 34.80 & 34.80 & 21,500 & 21,500 \\
\hline 20 & 126 & 124 & 9.07 & 1.80 & 1.80 & 1,240 & 981 \\
\hline 21 & 124 & 63 & 8.77 & 0.92 & 0.91 & 560 & 560 \\
\hline 22 & 124 & 99 & 6.45 & 0.40 & 0.40 & N/A & 576 \\
\hline 23 & 119 & 119 & 6.72 & 0.90 & 0.70 & 800 & 1,148 \\
\hline 24 & 115 & 106 & 2.62 & 0.30 & 0.30 & 342 & 420 \\
\hline 25 & 110 & 110 & 20.92 & 4.20 & 4.20 & N/A & 2,824 \\
\hline 26 & 107 & 95 & 31.64 & 12.70 & 12.70 & 3,800 & 4,000 \\
\hline 27 & 99 & 99 & 28.00 & 20.80 & 21.20 & 3,700 & 5,289 \\
\hline 28 & 98 & 98 & 85.44 & 22.50 & N/A & 10,716 & 12,464 \\
\hline 29 & 98 & 93 & 3.97 & 0.41 & 0.41 & 532 & 550 \\
\hline 30 & 95 & 72 & 4.98 & 4.50 & 4.30 & 4,040 & 4,130 \\
\hline 31 & 92 & 71 & 2.02 & 0.36 & 0.35 & 352 & 352 \\
\hline 32 & 91 & 91 & 8.18 & 0.86 & 0.86 & 624 & 658 \\
\hline 33 & 89 & 78 & 62.80 & 16.90 & 1.70 & 5,250 & 1,526 \\
\hline 34 & 87 & 81 & 1.76 & 0.59 & 0.59 & 139 & 126 \\
\hline
\end{tabular}




\begin{tabular}{|c|c|c|c|c|c|c|c|}
$\mathbf{3 5}$ & 87 & 87 & 6.68 & 2.20 & 2.20 & 1,099 & 2,356 \\
\hline $\mathbf{3 6}$ & 85 & 81 & 6.80 & 0.89 & 0.89 & 1,313 & 1,313 \\
\hline $\mathbf{3 7}$ & 83 & 83 & 1.83 & 0.60 & 0.60 & 312 & 320 \\
\hline $\mathbf{3 8}$ & 82 & 74 & 0.99 & 0.20 & 0.23 & 173 & 170 \\
\hline $\mathbf{3 9}$ & 80 & 80 & 4.97 & 0.72 & 0.72 & 856 & 792 \\
\hline $\mathbf{4 0}$ & 77 & 77 & 7.80 & 0.60 & 0.60 & 393 & 904 \\
\hline $\mathbf{4 1}$ & 75 & 70 & 25.39 & 5.00 & 5.00 & NA & NA \\
\hline $\mathbf{4 2}$ & 75 & 75 & 0.90 & 0.45 & 0.45 & 70 & 82 \\
\hline $\mathbf{4 3}$ & 74 & 74 & 3.55 & 0.50 & 0.50 & 606 & 540 \\
\hline $\mathbf{4 4}$ & 73 & 72 & 3.55 & 0.40 & 0.40 & 600 & 600 \\
\hline $\mathbf{4 5}$ & 69 & 66 & 38.11 & 6.46 & 6.42 & 4,735 & 4,735 \\
\hline $\mathbf{4 6}$ & 68 & 68 & 7.01 & 0.60 & 0.60 & 1,320 & 1,320 \\
\hline $\mathbf{4 7}$ & 67 & 67 & 9.93 & 3.30 & 3.10 & 1,400 & 1,618 \\
\hline $\mathbf{4 8}$ & 65 & 65 & 12.61 & 4.20 & 4.20 & 1,248 & 1,624 \\
\hline $\mathbf{4 9}$ & 64 & 52 & 38.81 & 5.40 & 5.40 & 3,500 & 3,500 \\
\hline $\mathbf{5 0}$ & 62 & 64 & 2.47 & 0.30 & 0.30 & 384 & 402 \\
\hline $\mathbf{5 1}$ & 62 & 56 & 19.11 & 2.10 & 2.10 & 3,288 & 3,520 \\
\hline $\mathbf{5 2}$ & 60 & 58 & 7.25 & 4.16 & 4.16 & 604 & 604 \\
\hline $\mathbf{5 3}$ & 60 & 60 & 7.67 & 2.89 & 2.89 & 880 & 816 \\
\hline $\mathbf{5 4}$ & 60 & 59 & 2.04 & 0.20 & 0.20 & 344 & 400 \\
\hline $\mathbf{5 5}$ & 56 & 55 & 34.55 & 3.80 & 1.90 & 3,540 & 2,528 \\
\hline $\mathbf{5 6}$ & 55 & 55 & 23.44 & 4.60 & 5.30 & 2,558 & 3,302 \\
\hline $\mathbf{5 7}$ & 55 & 54 & 0.33 & 0.33 & 0.33 & 49 & 49 \\
\hline $\mathbf{5 8}$ & 52 & 52 & 2.78 & 0.40 & 0.40 & 300 & 300 \\
\hline $\mathbf{5 9}$ & 52 & 51 & 14.14 & 1.51 & 1.51 & 518 & 532 \\
\hline $\mathbf{6 0}$ & 52 & 48 & 2.24 & 1.56 & 1.73 & 68 & 128 \\
\hline $\mathbf{6 1}$ & 50 & 50 & 6.00 & 18.28 & 18.28 & 397 & 397 \\
\hline $\mathbf{6 2}$ & 48 & 47 & 0.11 & 1.20 & 1.20 & 1 & 1 \\
\hline $\mathbf{6 3}$ & 37 & 37 & 0.55 & 0.70 & 0.60 & 48 & 48 \\
\hline $\mathbf{6 4}$ & 33 & 30 & 8.83 & 3.60 & 3.60 & 700 & 700 \\
\hline $\mathbf{6 5}$ & 26 & 26 & 109.00 & 14.00 & 9.90 & 4,558 & 6,556 \\
\hline & & & & & & \\
\hline $\mathbf{4 0}$ & & 52 & & & & & \\
\hline
\end{tabular}


Table 2 Linear Regression Results of the Length of Time from the First Application to the First Occupation Permit vs Gross Site Area

Dependent Variable: Length of Time from the First Application to the First Occupation Permit

Method: Least Squares

Included observations: 65

\begin{tabular}{lcccc}
\hline \hline \multicolumn{1}{c}{ Variable } & Coefficient & Std. Error & t-Statistic & Prob. \\
\hline \hline \multicolumn{1}{c}{ GSA } & 0.266545 & 0.842315 & 0.316443 & 0.7527 \\
\multicolumn{1}{c}{ C } & 98.82098 & 6.562637 & 15.05812 & 0.0000 \\
\hline \hline R-squared & 0.001587 & & & \\
Adjusted R-squared & -0.014261 & & & \\
F-statistic & 0.100136 & & & \\
Prob(F-statistic) & 0.752712 & & & \\
\hline \hline
\end{tabular}


Table 3 Linear Regression Results of the Length of Time from the First Application to the First Occupation Permit vs Gross Floor Area

Dependent Variable: Time from the First Application to the First

Occupation Permit

Method: Least Squares

Included observations: 65

\begin{tabular}{lrrrr}
\hline \hline \multicolumn{1}{c}{ Variable } & Coefficient & Std. Error & t-Statistic & Prob. \\
\hline \hline GFA & -0.104409 & 0.206726 & -0.505058 & 0.6153 \\
C & 101.5927 & 6.364518 & 15.96236 & 0.0000 \\
\hline \hline R-squared & 0.004033 & & & \\
Adjusted R-squared & -0.011776 & & & \\
F-statistic & 0.255084 & & & \\
Prob(F-statistic) & 0.615280 & & & \\
\hline \hline
\end{tabular}


Table 4 Linear Regression Results of the Length of Time from the First Successful Application to the First Occupation Permit vs Gross Site Area

Dependent Variable: Time from the First Successful Application to the First Occupation Permit

Method: Least Squares

Included observations: 65

\begin{tabular}{lrrrr}
\hline \hline \multicolumn{1}{c}{ Variable } & Coefficient & Std. Error & t-Statistic & Prob. \\
\hline \hline \multicolumn{1}{c}{ GSA } & 0.472241 & 0.794444 & 0.594430 & 0.5544 \\
\multicolumn{1}{c}{ C } & 91.34956 & 6.189670 & 14.75839 & 0.0000 \\
\hline \hline R-squared & 0.005577 & & & \\
Adjusted R-squared & -0.010207 & & & \\
F-statistic & 0.353347 & & & \\
Prob(F-statistic) & 0.554353 & & & \\
\hline \hline
\end{tabular}


Table 5 Linear Regression Results of the Length of Time from the First Successful Application to the First Occupation Permit vs Gross Floor Area

Dependent Variable: Time from the First Successful Application to the First Occupation Permit

Method: Least Squares

Included observations: 65

\begin{tabular}{lrrrr}
\hline \hline \multicolumn{1}{c}{ Variable } & Coefficient & Std. Error & t-Statistic & Prob. \\
\hline \hline GFA & -0.064996 & 0.195592 & -0.332303 & 0.7408 \\
C & 94.38336 & 6.021732 & 15.67379 & 0.0000 \\
\hline \hline R-squared & 0.001750 & & & \\
Adjusted R-squared & -0.014096 & & & \\
F-statistic & 0.110425 & & & \\
Prob(F-statistic) & 0.740764 & & & \\
\hline \hline
\end{tabular}




\section{Table 6 Data Description of the Independent Variables for Probit}

Analysis

\begin{tabular}{|c|c|c|c|c|}
\hline & DEVDENS & TOTALGFA & \multirow{7}{*}{$\begin{array}{c}\text { Number in NT } \\
\text { Number of non-NT }\end{array}$} & \multirow[t]{2}{*}{$\begin{array}{c}\text { New Territories } \\
\text { (NT) }\end{array}$} \\
\hline Mean & 104.62 & 135703.70 & & \\
\hline Median & 5.04 & 75197.00 & & 87 \\
\hline Maximum & 16170.96 & 1652800.00 & & 76 \\
\hline Minimum & 0.091752 & 195.0900 & & \\
\hline Std. Dev. & 1266.19 & 205013.40 & & \\
\hline Observations & 163 & 163 & & 163 \\
\hline
\end{tabular}




\section{Table 7 Probit Estimates for CDA First-Instance Applications}

Dependent Variable: IAPPROVED

Method: ML - Binary Probit (Quadratic hill climbing)

Date: 08/26/15

Time: 15:08

Sample: 1163

Included observations: 163

Convergence achieved after 7 iterations

QML (Huber/White) standard errors \& covariance

\begin{tabular}{crrrr}
\hline \hline Variable & Coefficient & Std. Error & z-Statistic & Prob. \\
\hline \hline NT & 0.460962 & 0.205515 & 2.242965 & 0.0249 \\
DEVDENS & -0.000220 & $4.41 \mathrm{E}-05$ & -4.991637 & 0.0000 \\
LOGGFA & 0.230916 & 0.163579 & 1.411644 & 0.1581 \\
C & -1.569601 & 0.817055 & -1.921048 & 0.0547 \\
\hline \hline McFadden R- & & & & \\
squared & 0.034175 & & 163 \\
\hline \hline Obs with Dep=0 & 96 & Total obs & \\
Obs with Dep $=1$ & 67 & & & \\
\hline \hline
\end{tabular}

